\title{
Genetic Disorders With Symptoms Mimicking Rheumatologic Diseases: A Single-Center Retrospective Study
}

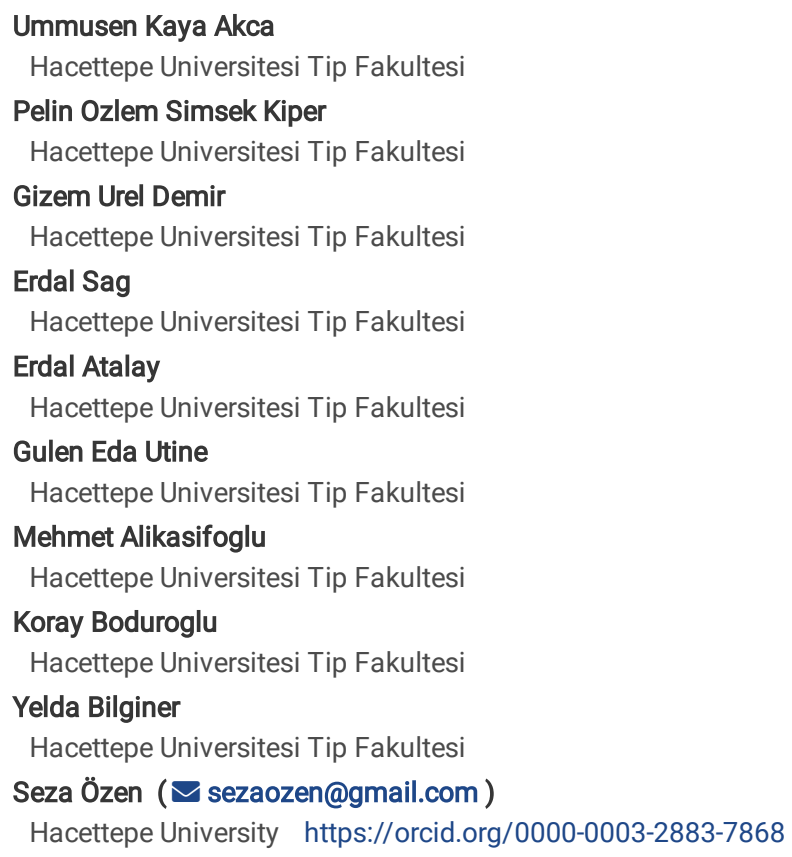




\section{Abstract}

\section{Background}

Musculoskeletal symptoms may be due to noninflammatory causes, including genetic disorders. We aimed to examine the final genetic diagnosis in patients who presented with musculoskeletal complaints to the rheumatology department.

\section{Methods}

Patients who presented to the Department of Pediatric Rheumatology and were referred to the pediatric genetic department between January 2015 and May 2019 were evaluated retrospectively.

\section{Results}

A total of 60 patients, 19 boys (31.66\%), with a mean age of $12.46 \pm 1.41$ years were included in the study. The total consanguinity rate was $25 \%$. The most common (29.5\%) cause of referral to the pediatric genetic department was the presence of skeletal anomalies (such as camptodactyly, clinodactyly, and short stature) with accompanying joint findings. Approximately one-third of the patients (n: 19) were diagnosed and followed up by the pediatric genetics department. The diagnoses of patients were as follows: camptodactyly, arthropathy, coxa vara, and pericarditis (CACP) syndrome (n: 3); trichorhinophalangeal syndrome (n: 1); progressive pseudorheumatoid dysplasia (n: 2); LIG4 syndrome (n: 1); H syndrome (n: 1); spondyloenchondrodysplasia (SPENCD) (n: 3); and nonspecific connective tissue disorders (n: 8).

\section{Conclusions}

In the differential diagnosis of patients who are referred to the Department of Pediatric Rheumatology with complaints of the musculoskeletal system, genetic disorders should also be considered.

\section{Background}

Musculoskeletal complaints may be the initial presenting symptoms in several genetic diseases (1). Musculoskeletal system symptoms may occur as part of genetic syndromes or genetic skeletal disorders that affect the development and growth of cartilage or bone. Patients with genetic skeletal disorders may present with disproportionate short stature, scoliosis, extremity anomalies (such as curvature in long tubular bones, brachydactyly, camptodactyly, limb asymmetry), or recurrent joint dislocation (2). Progressive pseudorheumatoid dysplasia (PPRD) and camptodactyly, arthropathy, coxa vara deformity, and pericarditis (CACP) syndrome can mimic juvenile idiopathic arthritis $(3,4)$. Accurate diagnosis is often delayed in these patients $(5)$, and the absence of inflammation (morning stiffness, redness, tenderness) signs and normal (laboratory) inflammatory markers may suggest non-rheumatologic diseases (6). A detailed history of symptoms; family history; pedigree of at least three generations; and systemic examination, including anthropometric measurements, laboratory tests, and radiologic examination are required to identify such genetic disorders (7). Accurate diagnosis of genetic disorders also helps in predicting the natural course and prognosis of the disease, providing proper genetic counseling, and avoiding unnecessary treatment.

We aimed to present our single-center experience on genetic disorders mimicking rheumatic diseases with similar symptoms. We hope that these cases will raise awareness for these genetic disorders, in the differential diagnosis for common diseases.

\section{Methods}

This study included a retrospective analysis of patients who were admitted to the pediatric rheumatology department with musculoskeletal complaints and were referred to the pediatric genetics department between January 2015 and December 2019. Hacettepe University is a main tertiary referral center for all subspecialties of pediatrics. In Turkey, the health expenses of all children younger than 18 are covered (including the refugees) and they are initially expected to present to a family doctor or State Hospital. Patients who presented to our center for the first time with musculoskeletal complaints were evaluated in the general pediatrics department and then referred to the pediatric rheumatology department, if necessary. In our study, each patient was referred to the Department of Genetics after being evaluated by a pediatric rheumatologist. Patients who were evaluated and diagnosed by another genetic center were not included in the study. The rate and degree of consanguinity, clinical diagnosis, indication for consultation, accompanying musculoskeletal and other findings were all recorded. Anthropometric measurements (height and weight) were obtained using the percentile values of Turkish children (8). Short stature was defined as a height that is 2 standard deviations (SD) or more below the mean for children of a particular sex and chronologic age. The diagnosis of genetic disorders was primarily based on a detailed history, including family history, pregnancy history, neonatal history, developmental milestones, and current schooling provision; physical examination including dysmorphology examination and assessment of behavioral phenotype; radiological evaluations when necessary; and genetic analysis. "Definite clinical and molecular diagnosis" was established through history, physical examination, radiologic assessments, and genetic analysis whenever available. Patients in whom no genetic etiology could be revealed, but the diagnosis was made on clinical and radiological grounds, were classified as "definite clinical diagnosis," and patients diagnosed with only clinical findings were classified as "strongly probable diagnosis" (9). We also evaluated patients who were first evaluated by the pediatric genetics department and then referred to the pediatric rheumatology department.

Ethical approval for this study was obtained (Project No: GO 19/781). Written informed consent was obtained from patients or their parents for the publication of genetic analysis results. Statistical analyses were performed using SPSS version 20. Descriptive statistics were presented as frequency, percentage, mean, $\mathrm{SD}$, and median values.

\section{Results}


Sixty out of 30,432 patients who presented to the pediatric rheumatology department over a 5-year period were referred to the pediatric genetics department (Fig. 1). A total of 60 patients, 19 boys (31.6\%), with a mean age of $12.46 \pm 1.41$ years were included in the study. The rate of consanguinity was $25.0 \%$; parental first cousin-marriage and $2^{\text {nd }}$ cousin marriages were detected in $10(16.6 \%)$ and $5(8.3 \%)$ families, respectively. The reasons for admission to the rheumatology department (in decreasing frequency) were as follows: joint swelling ( $n=15 / 60,25.0 \%)$, extremity deformity ( $n=12 / 60,20.0 \%)$, arthralgia $(n=11 / 60,18.3 \%)$, skin rash $(n=9 / 60,15.0 \%)$, abdominal pain and fever $(n=4 / 60,6.6 \%)$, Raynaud syndrome $(n=3 / 60,5.0 \%)$, and other reasons (oral aphthous ulcers, edema, dry mouth, and dry eye) in 6 (10.0\%) patients. Additionally, joint effusion was present in 15 patients.

The most frequent $(n=12 / 60,20 \%)$ reason for referral to the pediatric genetics department was the presence of skeletal anomalies, such as camptodactyly ( $\mathrm{n}$ : 7), clinodactyly (n: 6), and shortness in tubular bones (n: 3), as well as arthralgia and arthritis without an increase in acute phase reactants (n: 4), especially in the presence of parental consanguinity. Other causes of decreased frequency were as follows: accompanying findings, such as neurocutaneous findings and family history suggestive of a genetic syndrome $(n=11 / 60,18.3 \%)$, joint hyperlaxity $(n=10 / 60,16.6 \%)$, dysmorphic facial features ( $n=9 / 60,15 \%)$, joint deformity $(n=5 / 60,8.3 \%)$, multiple joint swelling without clinical and laboratory signs of inflammation $(n=5 / 60,8.3 \%)$, short stature $(n=4 / 60,6.6 \%)$, and abnormal radiological findings suggestive of a genetic disorder $(n=4 / 60,6.6 \%)$.

The most commonly affected joints in all patients, in general, were those in the hands, knees, and spine, whereas in 19 patients with genetic disorders, the most commonly affected joints were those in the hands, knees, and hips.

In the laboratory evaluation of eleven patients presenting with arthralgia, joint swelling, or effusion, acute phase reactants, including erythrocyte sedimentation rate and C-reactive protein concentrations, were all within normal laboratory reference values.

Among these 60 patients, $19(n=19 / 60,31.6 \%)$ had a final diagnosis of a genetic disorder. The diagnoses (in decreasing frequency) were as follows: nonspecific connective tissue disorders (n: 8), CACP syndrome (n: 3), spondyloenchondrodysplasia (SPENCD) (n: 3), PPRD (n: 2), trichorhinophalangeal syndrome (TRPS) (n: 1), LIG4 syndrome (n: 1), and H syndrome (n: 1). Parental consanguinity was detected in $25 \%$ of the patients, and this rate was similar among patients with genetic disorders. Two of the three patients who were diagnosed with SPENCD were siblings. The siblings or first-degree relatives of the patients with other diagnoses did not have a definitive genetic diagnosis.

Among patients with genetic diagnosis ( $n=19)$, six (31.5\%) had definite clinical and molecular diagnosis, while five (26.3\%) had definite clinical diagnosis. Clinical features of patients with definite clinical and molecular diagnosis and those with definite clinical diagnosis are shown in Table 1.

Eight patients are still being followed up in the pediatric genetics department with a strongly probable diagnosis of "nonspecific connective tissue disorder." These patients were examined for hereditary connective tissue disorders (HCTD) because joint hypermobility was detected on physical examination. Accompanying clinical findings included easy bruising ( $n: 3)$, pes planus ( $\mathrm{n}: 2)$, a history of spontaneous pneumothorax (n: 1), cardiac defect (n: 1), and striae (n: 1).

The remaining 41 patients without a definite diagnosis of genetic disease were divided into five groups: patients diagnosed with rheumatic disease at followup (n: 7), patients who were continually followed up by both the pediatric rheumatology and genetics departments (n: 18), patients followed up by the pediatric rheumatology department only (n: 8), patients followed up by the pediatric genetics department only (n: 6), and patients excluded from follow-up (n: 2) (Fig. 1).

Direct radiography findings contributed to the diagnosis, especially in six patients. Epiphyseal enlargement of the metacarpophalangeal and interphalangeal joints (patient 5), and enlarged epiphyses of the femoral heads, platyspondyly of vertebral bodies, anterior wedging of vertebrae, and erosion in the endplates (patient 6), were observed in patients with PPRD (Fig. 2). Radiologic examination of patient 4 revealed cone-shaped epiphyses that were highly suspicious for TRPS (Fig. 3). Moreover, radiological examination of the 9th, 10th, and 11th patients showed platyspondyly with irregular vertebral endplates, flattening of the posterior vertebral bodies, metaphyseal changes in the long bones, and enchondromatous lesions in the distal radius and ulna were consistent with the radiographic findings of SPENCD (Fig. 4).

A total 27 patients were referred to the pediatric genetics department in the same period. The reasons for the consultation were suspicion of autoinflammatory disease in 12 (44.4\%), followed by a search for juvenile idiopathic arthritis in 6 (22.2\%), rheumatological diseases accompanying genetic disorders in 5 (18.5\%), pre-diagnosis of chronic recurrent multifocal osteomyelitis in 2 (7.4\%), and Raynaud's disease in 2 (7.4\%) patients.

\section{Discussion}

In this study, 60 patients who were initially admitted to the Department of Pediatric Rheumatology but were thought to have genetic disorders were evaluated retrospectively. One-third of patients $(n=19 / 60,31.6 \%)$ who were subsequently evaluated at the pediatric genetics department were diagnosed with genetic disorders. Considering the high diagnosis rate, the threshold value should be kept low with regards to genetic disorders.

Non-rheumatic diseases are a substantial part of the pediatric rheumatology department referrals. As a result of a 3-year study conducted by the Pediatric Rheumatology Database Research Group in the United States, 12,939 patients were recorded in the registry and over $50 \%$ of them had non-rheumatic diagnosis (10). Similarly, among 3269 patients who presented to the pediatric rheumatology department between 1981 and 2004,2026 of them were diagnosed (61.9\%): rheumatic disease in 1032 (50.9\%) and non-rheumatic disease in 994 (49.1\%) of the patients (11). The distribution of non-rheumatic disease was orthopedic, mechanical or traumatic conditions (n:345), infection (n: 231), hematologic or neoplastic disease (n: 45), and a variety of other conditions ( $\mathrm{n}$ : 336). Genetic disorders were present in 14 of 336 patients in the other conditions category, with the most frequent (n: 4) being HCTD. In our study, a total of 30,432 patients presented to the pediatric rheumatology department over a period of 5 years. Among them, 60 were referred to the pediatric genetics department, and 19 (31.6\%) were diagnosed with genetic disorders, with HCTD being the most common diagnosis ( $n=8 / 19,42.1 \%)$ The fact that only 
60 of 30,432 patients who presented with musculoskeletal complaints were referred to the pediatric genetics department and that almost one-third of the referred patients were diagnosed, may be regarded as a "low yield."

Joint swelling, deformity in the extremity, arthralgia, and skin rash were the most common symptoms presented to the rheumatology department by the referred patients. We referred the patients to the pediatric genetic department due to the presence of skeletal anomalies, short stature, joint deformity, joint hyperlaxity, and dysmorphic findings; multiple anomalies, genetic disorders based on the results of the radiological examination; and the lack of clinical and laboratory signs of inflammation. They had some common features of skeletal dysplasias, such as short stature, ligamentous laxity, spinal deformity, progressive finger contractures, and extremity deformities $(12,13)$. Systemic physical examination, systemic findings, evaluation of growth and development, family history, and concomitant diseases provide an idea regarding possible genetic disorders (14).

Radiological examination has a crucial role in the diagnosis of rheumatologic diseases. Radiological imaging methods provide noninvasive information about the pathological processes that develop in the musculoskeletal system and help the diagnosis. Six patients with a definitive clinical diagnosis had direct radiography findings specific to the diagnosis in our study. Direct radiography, which is the basic method of imaging, provides a differential diagnosis as well as a diagnosis of rheumatological diseases (15). According to the European League against Rheumatism (EULAR)-Pediatric Rheumatology European Society (PReS) recommendations, direct radiography is recommended, especially to detect structural abnormalities (16).

Genetic skeletal disorders can mimic juvenile idiopathic arthritis. CACP syndrome (OMIM 208250) is a rare autosomal recessive disease characterized by early onset camptodactyly, noninflammatory arthropathy, progressive coxa vara deformity, and noninflammatory pericardial effusion. CACP is caused by a homozygous mutation in the PRG4 gene (OMIM 604283) on chromosome 1q31 (17). The gene encodes the protein lubricin, which is involved in the diffusive behavior of synovial fluid and contributes to the elastic absorption and energy dissipation of synovial fluid at physiologic shear frequencies (18). Joint findings of CACP syndrome may be confused with the joint findings of juvenile idiopathic arthritis (7). Many mutations have been identified in the PRG4 gene, and new mutations continue to be identified (19). Diagnosis of CACP is based on clinical, radiologic, and echocardiography findings. Genetic testing can confirm the diagnosis. However, the absence of a mutation does not rule out the diagnosis.

Another genetic skeletal disorder that may be confused with juvenile idiopathic arthritis is PPRD (OMIM 208230), which is an autosomal recessive disease caused by mutations in the WISP3 (Wnt1-inducible signaling pathway protein 3, OMIM 603400) gene. Patients usually present with polyarticular involvement and gait abnormalities. Subsequently, the involvement of the large joints and spine can cause severe joint contractures, hip disease, and spinal deformities $(20,21)$. Swelling in the interphalangeal joints may be confused with polyarticular juvenile idiopathic arthritis; however, inflammatory markers are normal and do not respond to antirheumatic therapy (22). Ekbote et al. reported 14 patients with PPRD and stated that all of them were misdiagnosed with inflammatory arthropathy at some point in their lives (23). Numerous WISP3 mutations have been reported. However, intronic mutations leading to splicing aberrations can only be extracted from cultured skin fibroblasts. As in our two patients diagnosed with PPRD, the absence of mutation in the WISP-3 gene does not rule out the diagnosis without making cultured skin fibroblasts. Al-Mayouf stated that genetic disorders, such as mucopolysaccharidosis and idiopathic multicentric osteolysis can also mimic juvenile idiopathic arthritis as PPRD and CACP (6).

TRPS tip 1 (OMIM 190350) is characterized by craniofacial and skeletal abnormalities. The main findings are sparse, thin hair, bulbous nasal tip, short stature, and cone-shaped epiphyses of the hands and feet, which were present in our patient (24). The diagnosis of TRPS is frequently based on clinical and radiological findings since the phenotype is often evident (25). We reported the case of a patient with clinical and radiological features (especially coneshaped epiphyses) that were highly suspicious for TRPS. However, a confirmatory genetic diagnosis was not available because we could not perform DNA sequence analysis.

SPENCD (OMIM 607944) is a rare autosomal recessive skeletal dysplasia, characterized by neurological involvement and immune dysfunction (26). SPENCD is a member of the interferonopathy group. Immune dysregulation in SPENCD may cause autoimmune diseases such as SLE, as in our 3 patients. Our patients had short stature, arthralgia/arthritis, lupus nephritis, hypocomplementemia, and positive autoantibodies. All of them showed dense intracranial calcifications on radiological examination. In three of these patients who were previously published, radiographic findings included metaphyseal changes in long tubular bones and platyspondyly in the vertebral bodies (27). Patients with SPENCD should be monitored for SLE and other comorbidities, while the possibility of SPENCD should be considered in SLE patients with proportionate short stature and skeletal abnormalities.

LIG4 syndrome (OMIM 606593), also known as DNA ligase IV syndrome, is a rare autosomal recessive disorder. LIG4-deficient patients have been reported to have immunodeficiency, abnormal facial features, growth retardation, and predisposition to malignancy (28). Most patients may have hypothyroidism and history of lung infection. Our patient had Behçet-like findings which have not been reported before, along with hypothyroidism, lung infection, and growth retardation (29).

$\mathrm{H}$ syndrome is an autosomal recessive condition, and common clinical features are hyperpigmentation, hypertrichosis, hepatosplenomegaly, hearing loss, heart anomalies, hypogonadism, low height, hyperglycemia, and hallux valgus/flexion contractures (30). In addition to these findings, patients may have cardiac anomalies, various hematologic abnormalities, pancreatic exocrine deficiency, recurrent febrile episodes, and lymphadenopathy (31). Our patient had no conditions other than hyperpigmented lesions, type 1 diabetes mellitus, hypogonadism, short stature, and joint contractures. Mutations in the SLC29A3 gene associated with $\mathrm{H}$ syndrome were detected.

HCTD are caused by genetic defects of proteins that constitute the connective tissue. The most common syndromes are benign joint hypermobility syndrome, Ehlers-Danlos syndrome, and Marfan syndrome (32). Skeletal, cardiovascular and respiratory, skin, and eye features may also be present. In the genetics discipline, nonspecific connective tissue disorder is considered according to the following scores: for systemic features $<7$ and/or borderline aortic root measurements $(Z<3)$, in the absence of FBN1 mutation (33). It may take years for clinical findings of each system to occur, such as ectopia lentis, aortic root

Page 4/10 
dilation, and mitral valve prolapse in children. Thus, a definite diagnosis may be delayed. Our patients who were followed up as possibly having HCTD, may have a definitive diagnosis on long-term follow-up.

This study has some limitations. We included a selected group of patients who were initially referred to the Department of Pediatric Rheumatology. Largerscale and multi-center studies are required. Despite this limitation, to the best of our knowledge, this study represents the first of its kind in the literature evaluating the diagnostic profile of referred patients.

\section{Conclusion}

In conclusion, concomitant diseases should be considered in patients who presented to the rheumatology outpatient clinics with musculoskeletal findings without inflammation,. Summarizing the genetic diagnostic spectrum detected in these patients will hopefully increase the awareness of the physicians involved in patients' care.

\section{Declarations}

Financial Disclosure: The authors have indicated they have no financial relationships relevant to this article to disclose.

Funding Source: No external funding for this manuscript.

Conflict of Interest: The other authors have indicated they have no potential conflicts of interest to disclose

Clinical Trial Registration: Hacettepe University Ethics Commission (Approval number: G0 19/781)

\section{Acknowledgments}

Not Applicable.

\section{Authors' contributions}

UKA conceptualized and designed the study, drafted the initial manuscript, reviewed and revised the manuscript. POSK contributed to the data collection, study design and as well as approved the final manuscript as submitted. GUD conceptualized and designed the study, and approved the final manuscript as submitted. ES drafted the initial manuscript and conceptualized the study. EA designed the study and drafted the initial manuscript. GEU contributed to the data collection and drafted the initial manuscript. MA contributed to the data collection and approved the final manuscript as submitted. KB coordinated and supervised data collection, approved the final manuscript as submitted. YB designed the study, critically reviewed and revised the manuscript. SO coordinated and supervised data collection, and critically reviewed and revised the manuscript.

\section{Availability of data and materials}

All data generated or analyzed during this study are included in this published article.

\section{Consent for publication}

All authors give consent for publication.

\section{Abbreviations}

CACP syndrome: Camptodactyly, arthropathy, coxa vara deformity, and pericarditis syndrome

EULAR: European League against Rheumatism

HCTD: Hereditary connective tissue disorders

PPRD: Progressive pseudorheumatoid dysplasia

PReS: Pediatric Rheumatology European Society

SPENCD: Spondyloenchondrodysplasia

TRPS: Tricho-rhino-phalangeal syndrome

\section{References}

1. Spencer $\mathrm{CH}$, Patwardhan A. Pediatric rheumatology for the primary care clinicians-recognizing patterns of disease. Curr Probl Pediatr Adolesc Health Care. 2015;45(7):185-206.

2. Calder AD, Foley P. Skeletal dysplasias: an overview. Paediatr Child Health. 2018;28(2):84-92.

3. Madhusudan S, Gupta A, Prakash M, Matta D, Suri D, Singh S. Camptodactyly-arthropathy-coxa vara-pericarditis (CACP) syndrome: a mimicker of juvenile idiopathic arthritis. Scand J Rheumatol. 2016;45(1):77-8. 
4. Garcia Segarra N, Mittaz L, Campos-Xavier AB, Bartels CF, Tuysuz B, Alanay Y, et al. The diagnostic challenge of progressive pseudorheumatoid dysplasia (PPRD): a review of clinical features, radiographic features, and WISP3 mutations in 63 affected individuals. Am J Genet C Semin Med Genet.

2012;15(3):217-29.

5. Albuhairan I, Al-Mayouf SM, editors. Camptodactyly-arthropathy-coxavara-pericarditis syndrome in Saudi Arabia: Clinical and molecular genetic findings in 22 patients. Semin Arthritis Rheum. 2013;43(2):292-6.

6. Al-Mayouf SM. Noninflammatory disorders mimic juvenile idiopathic arthritis. Int J Pediatr Adolesc Med. 2018;5(1):1-4.

7. Offiah AC, Woo P, Prieur A-M, Hasson N, Hall CM. Camptodactyly-arthropathy-coxa vara-pericarditis syndrome versus juvenile idiopathic arthropathy. AJR Am J Roentgenol. 2005;185(2):522-9.

8. Neyzi O, Bundak R, Gökçay G, Günöz H, Furman A, Darendeliler F, et al. Reference values for weight, height, head circumference, and body mass index in Turkish children. J Clin Res Pediatr Endocrinol. 2015;7(4):280.

9. Kurt-Sukur ED, Simsek-Kiper PO, Utine GE, Boduroglu K, Alanay Y. Experience of a skeletal dysplasia registry in Turkey: A five-years retrospective analysis. Am J Med Genet A. 2015;167(9):2065-74.

10. Bowyer S, Roettcher P. Pediatric rheumatology clinic populations in the United States: results of a 3 year survey. Pediatric Rheumatology Database Research Group. J Rheumatol. 1996;23(11):1968-74.

11. Rosenberg AM. Longitudinal analysis of a pediatric rheumatology clinic population. J Rheumatol. 2005;32(10):1992-2001.

12. Unger S. A genetic approach to the diagnosis of skeletal dysplasia. Clin Orthop Relat Res (1976-2007). 2002;401:32-8.

13. Brown R, Monsell F. Understanding the skeletal dysplasias. Curr Orthop. 2003;17(1):44-55.

14. Solomon BD, Muenke M. When to suspect a genetic syndrome. Am Fam Physician. 2012;86(9):826.

15. Matuszewska G, Zaniewicz-Kaniewska K, Włodkowska-Korytkowska M, Smorawińska P, Saied F, Kunisz W, et al. Radiological imaging in pediatric rheumatic diseases. Pol J Radiol. 2014;79:51-8.

16. Colebatch-Bourn A, Edwards C, Collado P, D'Agostino M, Hemke R, Jousse-Joulin S, et al. EULAR-PReS points to consider for the use of imaging in the diagnosis and management of juvenile idiopathic arthritis in clinical practice. Annals Rheum Dis. 2015;74(11):1946-57.

17. Taşar M, Eyileten Z, Kasımzade F, Uçar T, Kendirli T, Uysalel A. Camptodactyly-arthropathy-coxa vara-pericarditis (CACP) syndrome. J Pediatr. 2014;56:6846.

18. Jay G, Torres J, Warman M, Laderer M, Breuer K. The role of lubricin in the mechanical behavior of synovial fluid. Proc Natl Acad Sci. 2007;104(15):61949.

19. Mannurita SC, Vignoli M, Bianchi L, Kondi A, Gerloni V, Breda L, et al. CACP syndrome: identification of five novel mutations and of the first case of UPD in the largest European cohort. Eur J Med Hum Genet. 2014;22(2):197-201.

20. Pode-Shakked B, Vivante A, Barel O, Padeh S, Marek-Yagel D, Veber A, et al. Progressive Pseudorheumatoid Dysplasia resolved by whole exome sequencing: a novel mutation in WISP3 and review of the literature. BMC Med Genet. 2019;20(1):53.

21. Giray E, Yağcı İ, Elçioğlu HN. Progressive pseudorheumotoid dysplasia: A presentation of four cases with slow and rapid progression and effects of early rehabilitation program. Turk J Phys Med Rehabil. 2019;65(3):290.

22. Adak B, Tekeoĝlu I, Sakarya M, Uĝra S. Progressive pseudorheumatoid chondrodysplasia: a hereditary disorder simulating rheumatoid arthritis. Clin Rheumatol. 1998;17(4):343-5.

23. Ekbote AV, Danda D, Kumar S, Danda S, Madhuri V, Gibikote S, editors. A descriptive analysis of 14 cases of progressive-psuedorheumatoid-arthropathy of childhood from south India: review of literature in comparison with juvenile idiopathic arthritis. Semin Arthritis Rheum. 2013;42(6):582-9.

24. Vaccaro M, Guarneri C, Blandino A. Trichorhinophalangeal syndrome. J Am Acad Dermatol. 2005;53(5):858-60.

25. Maas S, Shaw A, Bikker H, Hennekam RC. Trichorhinophalangeal syndrome. GeneReviews ${ }^{8}$ [Internet]. Seattle (WA): University of Washington, Seattle; 1993-2020. Available from: https://www.ncbi.nlm.nih.gov/books/NBK425926/ 2017.

26. Girschick H, Wolf C, Morbach H, Hertzberg C, Lee-Kirsch MA. Severe immune dysregulation with neurological impairment and minor bone changes in a child with spondyloenchondrodysplasia due to two novel mutations in the ACP5 gene. Pediatr Rheumatol. 2015;13(1):37.

27. Bilginer Y, Düzova A, Topaloğlu R, Batu E, Boduroğlu K, Güçer Ş, et al. Three cases of spondyloenchondrodysplasia (SPENCD) with systemic lupus erythematosus: a case series and review of the literature. Lupus. 2016;25(7):760-5.

28. Altmann T, Gennery AR. DNA ligase IV syndrome; a review. Orphanet J Rare Dis. 2016;11(1):1-7.

29. Taskiran EZ, Sonmez HE, Kosukcu C, Tavukcuoglu E, Yazici G, Esendagli G, et al. A novel missense LIG4 mutation in a patient with a phenotype mimicking Behcet's disease. J Clin Immunol. 2019;39(1):99-105.

30. Molho-Pessach V, Ramot Y, Camille F, Doviner V, Babay S, Luis SJ, et al. H syndrome: the first 79 patients. J Am Acad Dermatol. 2014;70(1):80-8.

31. Meena D, Chauhan P, Hazarika N, Kansal NK. H Syndrome: a case report and review of literature. Indian J Dermatol. 2018;63(1):76.

32. Adib N, Davies K, Grahame R, Woo P, Murray K. Joint hypermobility syndrome in childhood. A not so benign multisystem disorder? Rheumatology. 2005;44(6):744-50.

33. Loeys BL, Dietz HC, Braverman AC, Callewaert BL, De Backer J, Devereux RB, et al. The revised Ghent nosology for the Marfan syndrome. J Med Genet. 2010;47(7):476-85.

\section{Table}


Table 1: Clinical, radiological and molecular features of patients with "definite clinical and molecular diagnosis" and "definite clinical diagnosis" 


\begin{tabular}{|c|c|c|c|c|c|c|c|c|c|}
\hline Gender & $\begin{array}{l}\text { Age } \\
\text { at } \\
\text { diagnosis }\end{array}$ & $\begin{array}{l}\text { History of } \\
\text { consanguinity } \\
\text { of families } \\
\text { (Degree of } \\
\text { consanguinity) }\end{array}$ & $\begin{array}{l}\text { Reason for } \\
\text { application to } \\
\text { rheumatology } \\
\text { department }\end{array}$ & Consultation indication & $\begin{array}{l}\text { Physical examination } \\
\text { findings }\end{array}$ & $\begin{array}{l}\text { Radiologic specific } \\
\text { findings }\end{array}$ & $\begin{array}{l}\text { Diagnosis } \\
\text { grouping }\end{array}$ & $\begin{array}{l}\text { Molecular } \\
\text { diagnosis }\end{array}$ & $\begin{array}{l}\text { Clinical } \\
\text { diagnosi }\end{array}$ \\
\hline Girl & 5 & $\begin{array}{l}\text { Yes } \\
\text { (1st degree } \\
\text { cousin } \\
\text { marriages) }\end{array}$ & $\begin{array}{l}\text { Swelling of } \\
\text { joints }\end{array}$ & Camptodactyly, arthritis & $\begin{array}{l}\text { Restriction in the } \\
\text { right elbow and both } \\
\text { wrists, swelling in } \\
\text { both hands and knee } \\
\text { joints, camptodactyly } \\
\text { in 2nd and 3rd } \\
\text { fingers of both } \\
\text { hands, limited } \\
\text { abduction of the } \\
\text { right hip }\end{array}$ & $\begin{array}{l}\text { Camptodactyly in the } \\
\text { hands }\end{array}$ & $\begin{array}{l}\text { Definite clinical } \\
\text { and molecular } \\
\text { diagnosis }\end{array}$ & $\begin{array}{l}\text { Homozygous } \\
P R G 4 \text { mutation }\end{array}$ & $\begin{array}{l}\text { CACP } \\
\text { syndrom }\end{array}$ \\
\hline Girl & 12 & $\begin{array}{l}\text { No (originated } \\
\text { from same } \\
\text { village) }\end{array}$ & $\begin{array}{l}\text { Swelling of } \\
\text { joints }\end{array}$ & $\begin{array}{l}\text { Camptodactyly, } \\
\text { clinodactyly, arthritis }\end{array}$ & $\begin{array}{l}\text { Extension limitation } \\
\text { in bilateral elbow } \\
\text { joints, camptodactyly } \\
\text { in the thumbs of both } \\
\text { hands, joint swelling } \\
\text { in the elbows, knees, } \\
\text { and left hip } \\
\text { restriction }\end{array}$ & $\begin{array}{l}\text { Camptodactyly in the } \\
\text { hands, }\end{array}$ & $\begin{array}{l}\text { Definite clinical } \\
\text { and molecular } \\
\text { diagnosis }\end{array}$ & $\begin{array}{l}\text { Homozygous } \\
P R G 4 \text { mutation }\end{array}$ & $\begin{array}{l}\text { CACP } \\
\text { syndrom }\end{array}$ \\
\hline Boy & 9 & No & $\begin{array}{l}\text { Swelling of } \\
\text { joints }\end{array}$ & $\begin{array}{l}\text { Curvature and joint } \\
\text { swelling in the fingers, } \\
\text { taken treatment as a JIA } \\
\text { patient but did not } \\
\text { benefit from it }\end{array}$ & $\begin{array}{l}\text { Extension restriction } \\
\text { in the joints of the } \\
\text { hand, camptodactyly } \\
\text { in } 3 \mathrm{rd}, 4 \text { th and } 5 \text { th } \\
\text { fingers of right hand } \\
\end{array}$ & $\begin{array}{l}\text { Camptodactyly in the } \\
\text { hands }\end{array}$ & $\begin{array}{l}\text { Definite } \\
\text { clinical diagnosis }\end{array}$ & $\begin{array}{l}\text { No PRG4 } \\
\text { mutation }\end{array}$ & $\begin{array}{l}\text { CACP } \\
\text { syndrom }\end{array}$ \\
\hline Girl & 12 & No & $\begin{array}{l}\text { Curvature of } \\
\text { her fingers }\end{array}$ & $\begin{array}{l}\text { Camptodactyly and facial } \\
\text { findings }\end{array}$ & $\begin{array}{l}\text { Clinodactyly in } 2 \text { nd, } \\
\text { 3rd, 4th fingers of } \\
\text { right hand and } \\
\text { middle finger of the } \\
\text { left hand. } \\
\text { Short structure, } \\
\text { prominent nose tip, } \\
\text { thin upper lip, and } \\
\text { sparse hair. } \\
\end{array}$ & $\begin{array}{l}\text { On hand MRI } \\
\text { imaging, epiphyseal } \\
\text { irregularities in the } \\
\text { PIF joint faces of } \\
\text { middle phalanges, } \\
\text { deformities, and } \\
\text { shortness of the 4th } \\
\text { and 5th metacarpes } \\
\text { of the right hand } \\
\end{array}$ & $\begin{array}{l}\text { Definite clinical } \\
\text { diagnosis }\end{array}$ & $\begin{array}{l}\text { No mutation in } \\
\text { the TRPS1 FISH } \\
\text { analysis }\end{array}$ & TRPS1 \\
\hline$\overline{\text { Girl }}$ & 12 & No & $\begin{array}{l}\text { Swelling of } \\
\text { joints for two } \\
\text { years }\end{array}$ & $\begin{array}{l}\text { Polyarticular involvement } \\
\text { without arthralgia and } \\
\text { normal acute phase } \\
\text { reactants response }\end{array}$ & \begin{tabular}{|l} 
Swelling and \\
enlargement in \\
proximal \\
interphalangeal \\
joints of 2-5th \\
fingers on right hand \\
\end{tabular} & $\begin{array}{l}\text { Epiphyseal } \\
\text { enlargement of the } \\
\text { metacarpophalangeal } \\
\text { and interphalangeal } \\
\text { joints }\end{array}$ & $\begin{array}{l}\text { Definite clinical } \\
\text { diagnosis }\end{array}$ & $\begin{array}{l}\text { No } \\
\text { WISP3 mutation }\end{array}$ & PPRD \\
\hline$\overline{\text { Boy }}$ & 16 & $\begin{array}{l}\text { Yes } \\
\text { (1st degree } \\
\text { cousin } \\
\text { marriages) }\end{array}$ & $\begin{array}{l}\text { Hip and low } \\
\text { back pain }\end{array}$ & $\begin{array}{l}\text { Compatible findings with } \\
\text { PPRD in thoracolumbar } \\
\text { MRI }\end{array}$ & $\begin{array}{l}\text { Low back pain and } \\
\text { swelling of knee and } \\
\text { elbow joints }\end{array}$ & $\begin{array}{l}\text { In radiological } \\
\text { examination of the } \\
\text { spine, platyspondyly } \\
\text { of vertebral bodies, } \\
\text { anterior wedging of } \\
\text { vertebrae, and } \\
\text { erosion in the end } \\
\text { plates. } \\
\text { Enlarged epiphyses } \\
\text { of the femoral heads. }\end{array}$ & $\begin{array}{l}\text { Definite } \\
\text { clinical diagnosis }\end{array}$ & $\begin{array}{l}\text { No } \\
\text { WISP3 mutation }\end{array}$ & PPRD \\
\hline Boy & 19 & $\begin{array}{l}\text { Yes } \\
\text { (2nd degree } \\
\text { cousin } \\
\text { marriages) }\end{array}$ & $\begin{array}{l}\text { Joint } \\
\text { swelling, oral } \\
\text { and genital } \\
\text { aphthae }\end{array}$ & $\begin{array}{l}\text { Accompanying } \\
\text { diseases (hypothyroidism, } \\
\text { growth hormone } \\
\text { deficiency, recurrent } \\
\text { meningitis and } \\
\text { respiratory problems, and } \\
\text { developmental delay) }\end{array}$ & $\begin{array}{l}\text { Short stature, normal } \\
\text { joint examination }\end{array}$ & - & $\begin{array}{l}\text { Definite clinical } \\
\text { and molecular } \\
\text { diagnosis }\end{array}$ & LIG4 mutation & $\begin{array}{l}\text { LIG4 } \\
\text { syndrom }\end{array}$ \\
\hline Girl & 14 & $\begin{array}{l}\text { Yes } \\
\text { (1st degree } \\
\text { cousin } \\
\text { marriages) }\end{array}$ & $\begin{array}{l}\text { Limited joint } \\
\text { range of } \\
\text { motion }\end{array}$ & $\begin{array}{l}\text { Accompanying } \\
\text { diseases (hyperpigmented } \\
\text { lesions, diagnosis of tip1 } \\
\text { diabetes mellitus, short } \\
\text { stature and signs of } \\
\text { hypogonadism) }\end{array}$ & $\begin{array}{l}\text { Short stature, } \\
\text { purple-black colored } \\
\text { hyperpigmented } \\
\text { lesions which were } \\
\text { more prominent on } \\
\text { the legs, contracture } \\
\text { in the proximal } \\
\text { in interphalangeal } \\
\text { joints of bilateral } \\
\text { hands } \\
\end{array}$ & - & $\begin{array}{l}\text { Definite clinical } \\
\text { and molecular } \\
\text { diagnosis }\end{array}$ & $\begin{array}{l}\text { Homozygous } \\
\text { deletion in exon } \\
3 \text { of SLC29A3 }\end{array}$ & $\begin{array}{l}\mathrm{H} \\
\text { syndrom }\end{array}$ \\
\hline Boy & 6 & No & \begin{tabular}{|l|} 
Arthralgia \\
and arthritis
\end{tabular} & $\begin{array}{l}\text { Physical examination and } \\
\text { radiologic findings }\end{array}$ & $\begin{array}{l}\text { Short stature, } \\
\text { arthritis of right first } \\
\text { metacarpophalangeal } \\
\text { joint, and arthralgia } \\
\text { of left knee, both } \\
\text { ankles, elbows, and } \\
\text { neck }\end{array}$ & $\begin{array}{l}\text { Platyspondyly with } \\
\text { irregular vertebral } \\
\text { endplates, flattening } \\
\text { of the posterior } \\
\text { vertebral bodies, } \\
\text { metaphyseal changes } \\
\text { in the long bones, } \\
\text { enchondromatous } \\
\text { lesions in distal } \\
\text { radius and ulna, and } \\
\text { dense calcifications } \\
\text { in the basal ganglia } \\
\end{array}$ & $\begin{array}{l}\text { Definite clinical } \\
\text { and molecular } \\
\text { diagnosis }\end{array}$ & $\begin{array}{l}\text { Homozygous } \\
A C P 5 \text { mutation }\end{array}$ & $\overline{\text { SPENCL }}$ \\
\hline Girl & 16 & No & $\begin{array}{l}\text { Arthralgia } \\
\text { and arthritis }\end{array}$ & $\begin{array}{l}\text { Physical examination and } \\
\text { radiologic findings }\end{array}$ & $\begin{array}{l}\text { Short stature, } \\
\text { arthralgia, and } \\
\text { arthritis of bilateral } \\
\text { metacarpophalangeal } \\
\text { joints }\end{array}$ & $\begin{array}{l}\text { Metaphyseal changes } \\
\text { in the long bones, } \\
\text { platyspondyly in the } \\
\text { vertebral bodies, and } \\
\text { dense intracranial } \\
\text { calcifications } \\
\end{array}$ & $\begin{array}{l}\text { Definite clinical } \\
\text { and molecular } \\
\text { diagnosis }\end{array}$ & $\begin{array}{l}\text { Homozygous } \\
A C P 5 \text { mutation }\end{array}$ & $\overline{\text { SPENCL }}$ \\
\hline
\end{tabular}




\begin{tabular}{|c|c|c|c|c|c|c|c|c|c|}
\hline Girl & 16 & $\begin{array}{l}\text { Yes } \\
\text { (1st degree } \\
\text { cousin } \\
\text { marriages) }\end{array}$ & $\begin{array}{l}\text { Malar rash, } \\
\text { fever, rash } \\
\text { and } \\
\text { arthralgia }\end{array}$ & $\begin{array}{l}\text { Physical examination and } \\
\text { radiologic findings }\end{array}$ & $\begin{array}{l}\text { Malar rash, } \\
\text { arthralgia, and short } \\
\text { stature. }\end{array}$ & $\begin{array}{l}\text { Platyspondyly in } \\
\text { vertebra and } \\
\text { metaphyseal changes } \\
\text { and dense } \\
\text { intracranial } \\
\text { calcifications }\end{array}$ & $\begin{array}{l}\text { Definite clinical } \\
\text { diagnosis }\end{array}$ & Not available & SPENCL \\
\hline
\end{tabular}

\section{Figures}

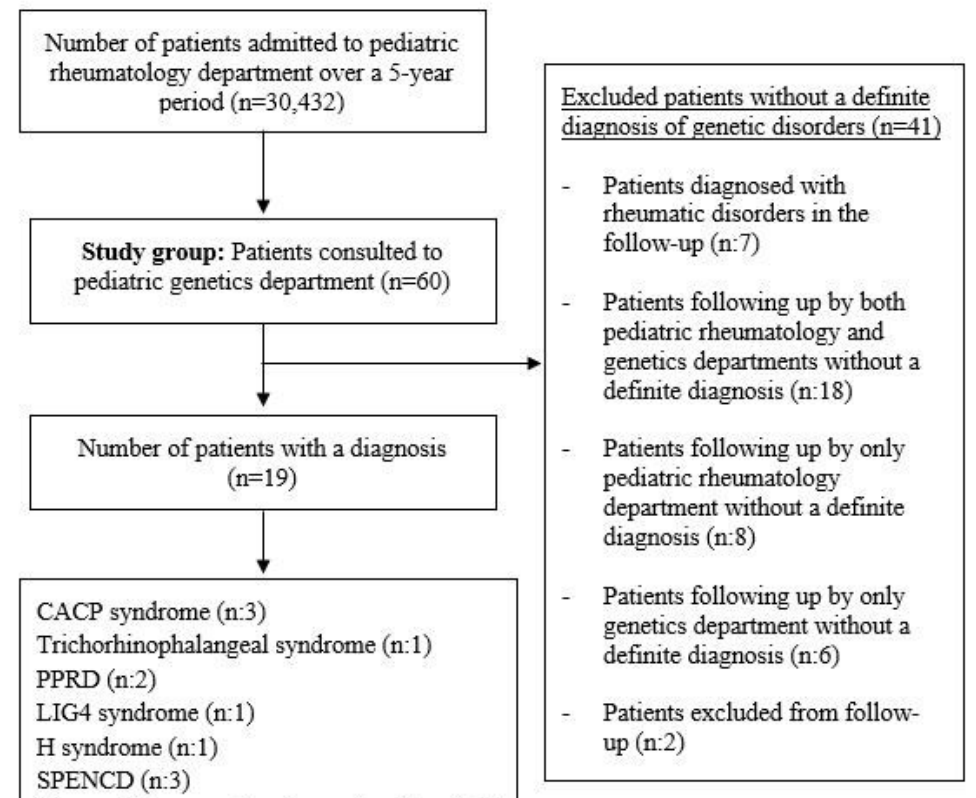

Abbreviations: CACP syndrome: camptodactyly arthropathy coxa vara pericarditis syndrome, PPRD: progressive pseudoromatoid dysplasia, SPENCD:

spondyloenchondrodysplasia

\section{Figure 1}

Flowchart of the study group

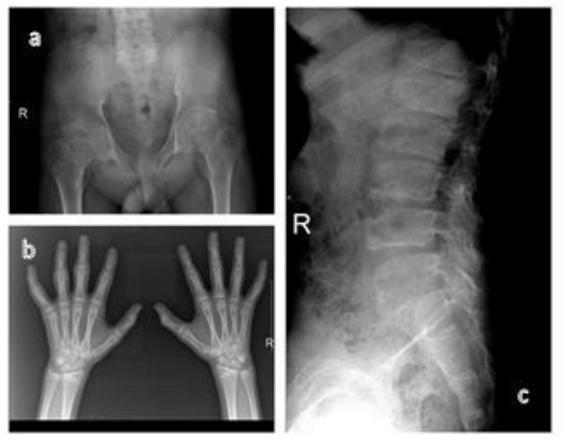

Figure 2

Radiological images of patients with PPRD (a: enlarged epiphyses of the femoral heads, b: epiphyseal enlargement of the metacarpophalangeal and interphalangeal joints, c: platyspondyly of vertebral bodies, anterior wedging of vertebrae, and erosion in the end plates) 


\section{Figure 3}

Patient 3: X-ray of the hands showing cone-shaped epiphyses of the 2 nd to 4 th middle phalanges

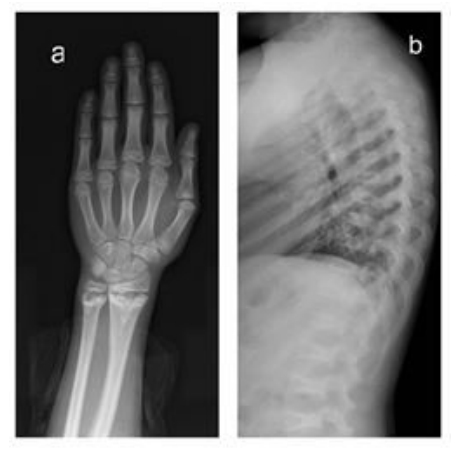

Figure 4

Radiological images of patients with SPENCD (a: metaphyseal changes in the long bones, b: platyspondyly with irregular vertebral endplates, flattening of the posterior vertebral bodies) 